\title{
Distribusi Dan Karakteristik Kualitas Perairan Ekosistem Mangrove Pulau Kecil Taman Nasional Bunaken
}

\author{
Joshian Nicolas William Schaduw
}

Fakultas Perikanan dan Ilmu Kelautan,Universitas Sam Ratulangi, Manado,Sulawesi Utara, Indonesia.

Email Koresponden: schaduw@unsrat.ac.id

Diterima: Januari 2018 /Disetujui: Februari 2018 / Publikasi online: Maret 2018

(c) 2018 Fakultas Geografi UGM dan Ikatan Geograf Indonesia (IGI)

\begin{abstract}
Abstrak Ekosistem mangrove mempunyai fungsi ekologi dan sosial ekonomi bagi masyarakat pesisir, mempertahankan fungsi ini merupakan langkah mempertahankan fungsi ekosistem disekitarnya diantaranya terumbu karang dan padang lamun. Kajian ini menganalisa kondisi kualitas perairan ekosistem mangrove yang ada pada empat pulau kecil di Taman Nasional Bunaken (Pulau Bunaken; Pulau Manado Tua; Pulau Mantehage; Pulau Nain) dan korelasi karakterisitik kualitas air pulau-pulau tersebut (suhu, salinitas, kekeruhan, total suspended solid, pH, Dissolved Oksigen, NO3-N, dan PO4-P) dengan menggunakan Principal Component Analysis (PCA), kajian ini menggunakan instrumen pengukuran kualitas air in situ dan ex situ di laboratorium. Selain itu, hasil kualitas air ini akan dibandingkan dengan baku mutu yang telah ditetapkan pemerintah pada ekosistem mangrove, hal ini sebagai bahan pertimbangan pengelolaan ekosistem mangrove dimasa yang akan datang. Hasil yang diperoleh dari kajian ini adalah kualitas air keempat pulau ini masuk dalam kategori baik dan dapat mendukung kelangsungan hidup biota yang berasosisi didalamnya. Korelasi karakteristik kualitas air sebesar 94\%, faktor utama 1 (F1) 79,33\% dan faktor utama 2 (F2) 14,22\% dengan penciri utama suhu, PO4-P, dan salinitas, dendogram menunjukkan adanya dua tingkatan hubungan kekerabatan dimana Pulau Nain dan Pulau Manado Tua memiliki kekerabatan kondisi perairan yang sama, diikuti Pulau Bunaken dan Mantehege. Kondisi ini harus dipertahankan dan dimonitoring secara berkala mengingat Taman Nasional Bunaken banyak mendapat tekanan dari aktivitas antropogenik dan perubahan iklim global.
\end{abstract}

Kata Kunci : Mangrove; Bunaken; Kualitas air; PCA.

\begin{abstract}
Mangrove ecosystems have ecological and socio-economic functions for coastal communities, preserve these functions is a step to maintain the function of adjacent ecosystems including coral reefs and seagrass beds. This study analyzed the water quality conditions of mangrove ecosystem within four small islands in Bunaken National Park (Bunaken Island, Manado Tua Island, Mantehage Island and Nain Island) and water quality characteristic correlation among these islands (e.g. temperature, salinity, turbidity, total suspended solid, pH, Dissolved Oxygen, NO3-N, and PO4-P) using Principal Component Analysis (PCA), this study used laboratory in situ and ex situ water quality measurement instruments. In addition, the results of this water quality then compared with the government standard quality for mangrove ecosystem water quality, this is a consideration for the management of mangrove ecosystems in the future. The results obtained from this study shows the water quality of these four islands in the category of good and can support the existence of associate biota that live in it. The correlation of water quality characteristic was $94 \%$, main factor 1 (F1) 79,33\% and main factor 2 (F2) 14,22\% with main characteristics are temperature, PO4-P, and salinity, grouping these characteristics through dendogram showed two levels of relationship where Nain Island and Manado Tua Island have the same relationship of their water condition, followed by Bunaken Island and Mantehege. This condition must be maintained and monitored regularly as Bunaken National Park is under considerable get pressure from anthropogenic activities and global climate change.
\end{abstract}

Keywords: Mangrove; Bunaken; Water quality; PCA

\section{PENDAHULUAN}

Kondisi perairan suatu ekosistem pesisir sangat mempengaruhi produkfitas dan fungsi dari ekosistem tersebut. Poedjirahajoe (2011) menyatakan bahwa, faktor habitat sangat berpengaruh terhadap komposisi penyusun ekosistem mangrove bahkan perubahan kualitas habitat secara kompleks dapat mengakibatkan pergeseran jenis vegetasi penyusunnya. Jenis vegetasi yang mampu beradaptasi pada kondisi habitat yang mengalami perubahan dikhawatirkan dapat mendominasi kawasan tersebut sehingga menyebabkan terjadinya penurunan keanekaragaman jenis di dalam kawasan. Dalam pengelolaan kawasan mangrove perlu diketahui kondisi ekologis habitat yang sesuai dengan jenis tanaman yang ada pada ekosistem tersebut. Ekosistem mangrove dapat diartikan sebagai ekosistem yang ditumbuhi oleh berbagai vegetasi khas mangrove yang tidak dapat digantikan oleh vegetasi lainnya. Vegetasi tersebut sangat khas baik dalam hal penampakan (habitus) hingga pengelompokan 
(clustering). Untuk dapat bertahan hidup pada konsisi habitat tersebut, vegetasi mangrove mempunyi pola adaptasi tertentu, mulai dari adaptasi peakaran, adaptasi daun hingga adaptasi bunga dan buah. Salah satu bentuk adaptasi yang khas adalah membentuk struktur komunitas, memiliki pola asosiasi dan zonasi tertentu (Hilmi et al, 2015).

Kualitas perairan ekosistem mangrove sangat mempengaruhi kondisi kesehatan tumbuhan mangrove, walaupun tumbuhan ini terkenal dengan tumbuhan yang memiliki adaptasi yang tinggi terhadap perubahan salinitas, tumbuhan ini juga rentan terhadap perubahan kualitas airnya seperti suhu, $\mathrm{pH}$, dan DO. Ketidakstabilan parameter kualitas air tersebut akan mengakibatkan penurunan kualitas bahkan kematian pada mangrove.

Luas total ekosistem mangrove pulau kecil Taman Nasional Bunaken (TNB) mencapai 977,630 ha yang tersebar diempat pulau. Terdapat delapan jenis mangrove yang teridentifikasi di Pulau Mantehage, yaitu : Rhizophora mucronata, Rhizophora apiculata, Rhizophora stylosa, Bruguiera gymnorrhiza, Bruguiera cylindrical, Ceriopstagal, Sonneratiaalba, dan Lumnitzera littorea, luasan mangrove pulau ini mencapai luas 893,8 ha (Lahabu et al, 2015 dan Schaduw, 2012). Pulau Bunaken dengan luas mangrove 71,576 ha, memiliki lima jenis mangrove yaitu Soneratia alba, Avicennia marina, Xylocarpus granatum, Rhizophora apiculata, dan Bruguiera gymnorrhiza, yang terbagi dalam empat family yaitu Sonneratiaceae, Avicenniaceae, Meliaceae, dan Rhizophoraceae. (Schaduw, 2016), Pulau Manado tua dengan luas 7,814 ha memiliki dua jenis mangrove yaitu jenis Avicennia alba dari family Avicenniaceae dan Rhizophora mucronata dari family Rhizophoraceae (Schaduw, 2012), Pulau Nain ini memiliki dua jenis mangrove yaitu jenis Rhizophora apiculata dan Avicennia marinna masing-masing dari family Avicenniaceae dan Rhizophoraceae dengan luas 4,4 ha. Berbeda halnya dengan kondisi jenis mangrove di Rarowatu Utara, Bombana Sulawesi Tenggara yang meliputi dua desa yaitu Desa Watumentade dan Desa Tunas Baru diperoleh hasil terdapat 6 jenis vegetasi mangrove, antara lain Alba, Avicennia marina, Sonneratia alba, Lumnitzera litorrea, Bruguiera gimnorrhiza dan Rhizophora apiculata (Alimuna et al, 2009), sedangkan jumlah jenis mangrove yang ada di Andai Kabupaten Manokwari komposisi jenis vegetasi penyusun hutan mangrove Andai untuk tingkat semai terdiri dari 31 jenis (22 genus dan 17 family), tingkat pancang 29 jenis (17 genus dan 11 family), dan tingkat pohon 30 jenis (18 genus dan 11 family) (Matan et al, 2010). Berdasarkan kajian Arizona dan Sunarto (2009) di Kampung Tobati Jayapura jenis mangrove didominasi genus Rhizophoraceae dengan jenis Rhizophora mucronata, Rhizophora apiculata dan Rhizophora siylosa, sedangkan Kampung Nafri ditemukan 9 jenis mangrove sejati yaitu : Aviccenia marina, Rhizophora mucronata, Rhizophora apiculata, Sonneratia alba, Aegiceras comiculatum, Ceriops tagal, Bruguiera gymnorrhiza, Scyphiphora hydrophyllacea,dan Nypa fructicans. Tingginya keanekaragaman mangrove membuat ekosistem ini sangat penting untuk dilestarikan, ekosistem mangrove memberikan kontribusi yang sangat besar bagi produktivitas perairan pesisir, transport bahan organik, pelindung pantai, perduksi bahan pencemar, dan tempat migrasi onthogenik biota yang berasosiasi di dalamnya.

Kajian ini bertujuan untuk menganalisa kondisi kualitas air ekosistem mangrove pulau kecil yang ada pada Taman Nasional Bunaken. Keempat pulau yang menjadi objek penelitian adalah Pulau Mantehage, Pulau Bunaken, Pulau Manado Tua, dan Pulau Nain. Nilai strategis dari lokasi penelitian anatara lain Pulau Mantehage adalah salah satu Pulau terluar Indonesia di Sulawesi utara yang memiliki luasan mangrove terbesar, Pulau Bunaken adalah destinasi wisata kelas dunia untuk keindahan bawah laut, sedangkan Pulau Nain adalah salah satu sentra budidaya rumput laut Sulawesi utara. Selain itu tingginya aktivitas manusia dan pengaruh perubahan iklim di pulau kecil akan meningkatkan kerentanan ekosistem ini. Manfaat dari kajian ini adalah sebagai bahan masukkan untuk pengambil kebijakan, khususnya pengelola Taman Nasional Bunaken untuk pengembangan dan pelestarian ekosistem mangrove yang ada di sana.

\section{METODE PENELITIAN \\ Waktu dan Lokasi Penelitian}

Penelitian ini dilakukan pada ekosistem mangrove yang ada di empat pulau kecil Taman Nasional Bunaken diantaranya Pulau Mantehage, Pulau Bunaken, Pulau Manado Tua, dan Pulau Siladen. Taman Nasional Bunaken memiliki lima pulau kecil, hanya saja Pulau Siladen tidak memiliki ekosistem mangrove. Masingmasing pulau ini memiliki jumlah Desa yang berbeda, sehingga stasiun pengamatan diambil pada masingmasing desa. Kajian ini menggunakan 4 Stasiun (pulau) dan 8 Sub stasiun (desa). Taman Nasional Bunaken masuk dalam wilayah administrasi Kota Manado dan Kabupeten Minahasa Utara, Provinsi Sulawesi Utara (Gambar 1). Kajian ini dilakukan pada bulan November 2017.

\section{Jenis dan Analisis data}

Variabel penelitian ini adalah suhu, salinitas, kekeruhan, total suspended solid, $\mathrm{pH}$, Dissolved Oksigen, NO3-N, dan PO4-P. Pada setiap pulau stasiun pengamatan ditempatkan pada masing-masing desa. Pulau Mantehage empat desa, Pulau Bunaken dua desa, Pulau Manado Tua satu desa, dan Pulau Nain satu Desa. Setiap jalur dibagi menjadi tiga zona, yaitu proksimal, medial, dan distal yang masing-masing zona diambil tiga kali ulangan. Semakin tebal mangrove maka jarak antar zona akan semakin panjang dan sebaliknya. 


\section{Kualitas Air}

Parameter yang dapat diukur di lapangan (in situ) seperti salinitas, suhu, DO, dan $\mathrm{PH}$ langsung diukur dan dicatat hasilnya, kemudia dianalisa secara deskriptif dan tabulasi. Pada kajian ini alat yang digunakan adalah Horiba for Water Quality, sedangkan untuk TSS, Kekeruhan, NO-3N dan PO4-P sampel dimasukkan dalam wadah botol kaca (ex situ), kemudian dianalisis di Laboratorium Biologi Laut Fakultas Perikanan dan Ilmu Kelautan Universitas Sam Ratulangi Manado, untuk varibel TSS, Kekeruhan, NO-3N dan PO4-P analisa dilakukan di laboratorium dengan menggunakan metode analisa yang digunakan Kurniadi et al, (2015).

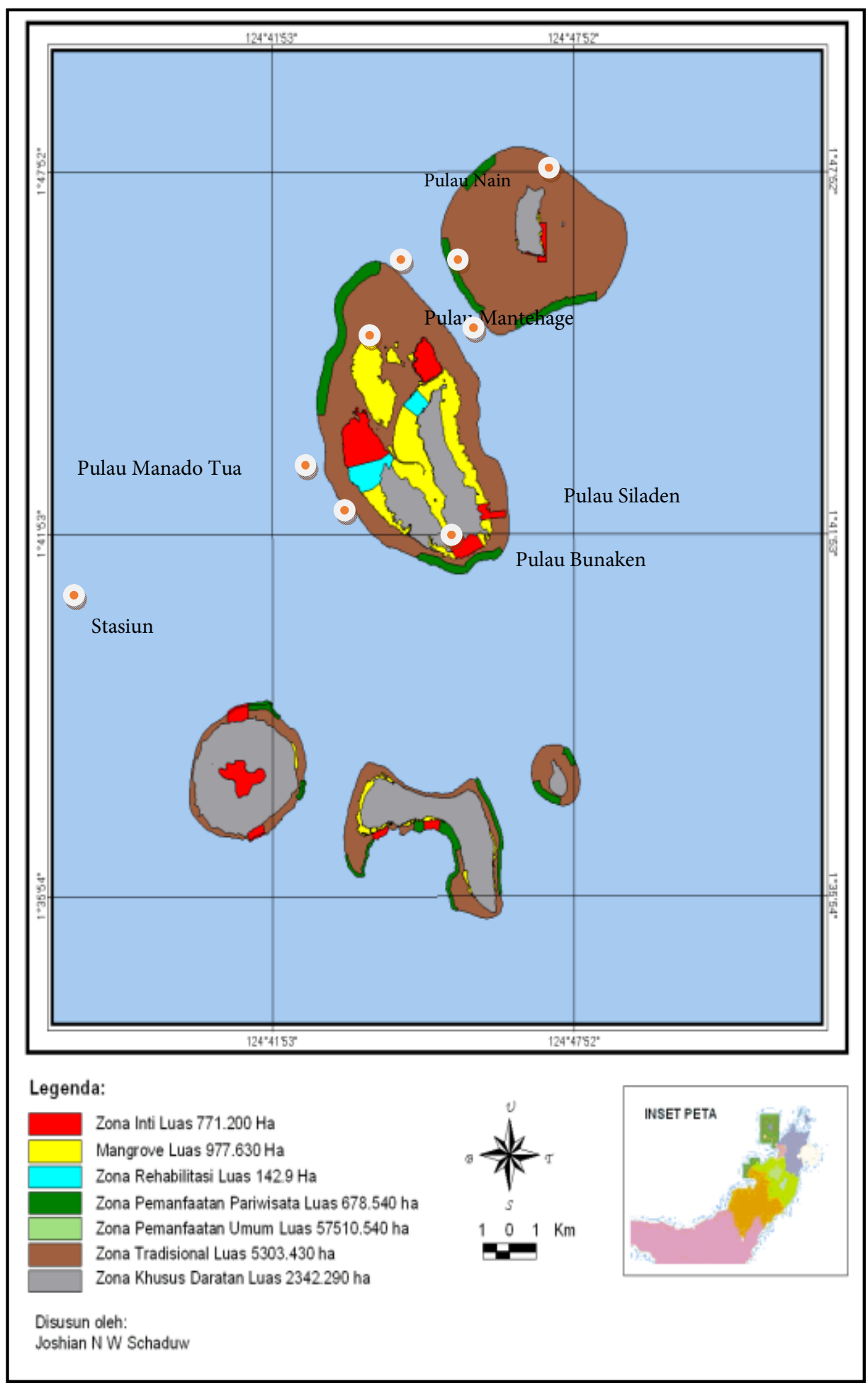

Gambar 1. Peta Lokasi Penelitian Pulau-Pulau Kecil Taman Nasional Bunaken Principle Components Analysis 
Untukmelihathubunganantarstasiun pengamatan penelitian berdasarkan variabel yang diukur digunakan Analisis Komponen Utama (Principle Components Analysis). Metode ini bertujuan mendeterminasi sumbu-sumbu optimum tempat diproyeksikannya individu-individu dan / atau variabel-variabel. Untuk menentukan hubungan antara dua variabel digunakan pendekatan matriks korelasi yang dihitung dari indeks sintetik (Ludwig dan Reynolds, 1988), Indeks yang digunakan adalah indeks tertinggi dan terendah masing-masing atribut setiap dimensi, jadi dalam kasus ini ada delapan indeks dari empat pulau objek penelitian. PCA merupakan metode statistik deskriptif yang bertujuan menyajikan informasi maksimum suatu matriks data kedalam bentuk grafik (Bengen 2000; Bakus 2007). Matriks tersebut terdiri dari stasiun penelitian yang dalam hal ini adalah PPK TNB (matriks baris), serta karakter suhu, salinitas, kekeruhan, total suspended solid, pH, Dissolved Oksigen, NO3-N, dan PO4-P (matriks kolom). Dalam menganalisa, masingmasing karakter dianalisa secara terpisah. Karena data tersebut tidak mempunyai unit pengukuran yang sama, maka data ini dinormalisasikan lebih dahulu melalui pemusatan dan pereduksian. Dengan demikian nilai PCA tidak direalisasikan dari nilai-nilai parameter inisial, tetapi dari indeks sintetik yang diperoleh dari kombinasi linier nilai-nilai parameter inisial. Analisis ini bertujuan untuk Untuk mengekstraksi informasi yang terdapat dalam matriks data yang berukuran besar; menghasilkan suatu representasi grafik yang memudahkan interpretasi dan mempelajari suatu matriks data dari sudut pandang kemiripan antara individu atau hubungan antara variabel. Ludwig dan Reynolds, (1988) menyederhanakan persamaan ini sebagai berikut: Rs x s = As x n At n x s dimana: Rs x s = Matriks korelasi rij; As $\mathrm{x} n=$ Matriks indeks sintetis rij; At $\mathrm{n} \times \mathrm{s}=$ Matriks transpose (pertukaran bariskolom) dari matriks A

Semakin kecil jarak Euclidean antara dua variabel maka semakin mirip karakteristik variabel tersebut. Selain itu dengan analisa PCA ini maka kita dapat menentukan variabel yang menjadi peubah penting dalam penelitian ini (Legendre \& Legendre, 2014). Pengelohan data dilakukan dengan menggunakan program XL STAT.

\section{HASIL DAN PEMBAHASAN}

\section{Suhu}

Kondisi suhu pada perairan ekosistem mangrove pulau-pulau kecil TNB tergolong baik dan masih sesuai dengan baku muta untuk biota laut serta untuk kegiatan pariwisata. Suhu perairan bagian depan kearah laut lebih tinggi dibandingkan bagian tengah dan belakang, hal ini dipengaruhi penetrasi cahaya matahari terhadap kolom air. Bagian belakang ekosistem ini yang berdekatan dengan daratan ditutupi oleh kanopi mangrove, sehingga suhu pada bagian ini cederung rendah. Suhu perairan tertinggi pada pulau Nain dan Pulau Manado $\left(29,67^{\circ} \mathrm{C}\right)$, sedangkan suhu terendah adalah pulau Mantehage $\left(28,96^{\circ} \mathrm{C}\right)$ (Tabel 1). Untuk data yang lebih rinci tentang kondisi suhu pulau kecil dapat dilihat pada Tabel 1. Kondisi suhu ini juga dipengaruhi oleh luas dari ekosistem mangrove, terindikasi pulau yang memiliki ekosistem mangrove yang besar kondisi suhu perairan lebih rendah dibandingkan yang kecil. Suhu perairan Kabupaten Barru berkisar antara $30,2^{\circ} \mathrm{C}-30,3^{\circ} \mathrm{C}$ (Malik, 2013), sedangkan suhu perairan ekosistem mangrove di distrik Liquisa Timor Leste dikisarn $28^{\circ} \mathrm{C}-30^{\circ} \mathrm{C}$ (Jesus, 2012), kajian Wantasen (2013) di perairan ekosistem mangrove Desa Basaan I terhadap suhu perairan menunjukkan angka $31^{\circ} \mathrm{C}$, suhu peraian ekosistem mangrove pada patung Ngurah Rai Tuban Denpasar memiliki nilai rata-rata $29,1^{\circ} \mathrm{C}$ (Suriani, 2006). Kajian kualitas air di Sungai Buaya di Pulau Bunyu Kalimantan Utara mendapatkan nilai rata-rata pengukuran suhu berkisar antara $28-28,5^{\circ} \mathrm{C}$ pada saat pasang dan $28-29,3$ ${ }^{0} \mathrm{C}$ saat surut, tidak terdapat perbedaan yang besar baik saat pasang maupun surut (Kurniadi, 2015). Ulqodry et al, (2010) dalam kajiannya di perairan mangrove Tanjung Api-api Sumatera Selatan mendapatkan hasil pengukuran suhu berkisar $27,6^{\circ} \mathrm{C}-30,4^{\circ} \mathrm{C}$. Sedangkan suhu air pada ekosistem mangrove di Kampung Tobati dan Kampung Nafiri Jayapura berkisar $26,33{ }^{\circ} \mathrm{C}-32,17$ ${ }^{0} \mathrm{C}$ (Arizona dan Sunarto, 2009). Suhu yang baik untuk mangrove tidak kurang dari $20^{\circ} \mathrm{C}$ (Kolehmainen et al, 1974). Suhu merupakan salah satu faktor eksternal yang paling mudah untuk diteliti dan ditentukan. Aktivitas metabolisme serta penyebaran organisme air banyak dipengaruhi oleh suhu air. Pada umumnya suhu permukaan perairan adalah berkisar antara $28^{\circ} \mathrm{C}-31^{\circ} \mathrm{C}$ (Nontji, 2005). Mangrove dapat tumbuh dengan baik pada daerah tropis dengan temperatur di atas $20^{\circ} \mathrm{C}$ (Aksornkoae, 1993). Suhu merupakan salah satu faktor yang sangat menentukan dalam proses metabolisme organisme di perairan. Suhu yang mendadak berubah atau terjadinya perubahan suhu yang ekstrim akan mengganggu kehidupan organisme atau dapat menyebabkan kematian. Suhu perairan dapat mengalami perubahan sesuai dengan musim, letak lintang suatu wilayah, letak tempat terhadap garis edar matahari, sirkulasi udara, penutupan awan, aliran air, waktu pengukuran dan kedalaman air.

\section{Kekeruhan}

Nilai rata-rata kekeruhan pada keempat pulau ini cenderung diatas nilai baku mutu $(<5 \mathrm{NTU})$, akan tetapi dua lokasi nilai ini berada dibawah baku mutu yaitu pada bagian depan Pulau Mantehage (4,45 NTU) dan depan Pulau Bunaken (3,70 NTU). Tingginya nilai kekeruhan ini tentu saja berkaitan dengan substrat dari ekosistem mangrove yang didominasi lumpur dan masukkan material dari daratan. Nilai rata-rata kekeruhan ini berkisar antara 5,41-5,94 NTU (Tabel 1). Walapun nilai 
Joshian Nicolas William Schaduw/Majalah Geografi Indonesia, Vol. 32, No. 1, Maret 2018 : 40 - 49

\begin{tabular}{|c|c|c|c|c|c|c|c|c|c|}
\hline \multirow{5}{*}{ Pulau } & \multicolumn{8}{|c|}{ Tabel 1. Nilai rata-rata parameter kualitas air } & \multirow[b]{2}{*}{$\mathrm{mg} / \mathrm{I}$} \\
\hline & Satuan & $\mathrm{C}$ & NTU & $\mathrm{mg} / \mathrm{L}$ & & PSU & $\mathrm{mg} / \mathrm{L}$ & $\mathrm{mg} / \mathrm{L}$ & \\
\hline & Biota & $28-32$ & $<5$ & 80 & $7-8.5^{(\mathrm{d})}$ & $<34$ & $>5$ & 0.008 & 0.015 \\
\hline & Pariwisata & alami & $<5$ & 20 & $7-8.5^{(\mathrm{d})}$ & $\operatorname{alami}^{3}(\mathrm{e})$ & $>5$ & 0.008 & 0.015 \\
\hline & Parameter & Suhu & Kekeruhan & TSS & $\mathrm{pH}$ & Salinitas & DO & NO3-N & PO4-P \\
\hline \multirow{4}{*}{ Mantehage } & Belakang & 28,25 & 6,41 & 47,50 & 7,96 & 28,25 & 5,08 & 0,07 & 0,37 \\
\hline & Tengah & 28,75 & 5,93 & 37,75 & 8,19 & 29,00 & 5,59 & 0,06 & 0,18 \\
\hline & Depan & 29,88 & 4,45 & 28,50 & 8,26 & 30,00 & 6,40 & 0,03 & 0,17 \\
\hline & Rata-rata & 28,96 & 5,60 & 37,92 & 8,14 & 29,08 & 5,69 & 0,05 & 0,24 \\
\hline \multirow{4}{*}{ Bunaken } & Belakang & 28,50 & 6,33 & 49,00 & 7,84 & 28,50 & 4,92 & 0,04 & 0,05 \\
\hline & Tengah & 29,00 & 6,20 & 36,00 & 8,16 & 29,50 & 5,99 & 0,06 & 0,06 \\
\hline & Depan & 29,50 & 3,70 & 26,00 & 8,21 & 30,00 & 6,40 & 0,02 & 0,03 \\
\hline & Rata-rata & 29,00 & 5,41 & 37,00 & 8,07 & 29,33 & 5,77 & 0,04 & 0,05 \\
\hline \multirow{4}{*}{ Manado Tua } & Belakang & 29,00 & 6,23 & 38,00 & 8,13 & 30,00 & 4,73 & 0,03 & 0,04 \\
\hline & Tengah & 30,00 & 6,18 & 25,00 & 8,21 & 30,00 & 5,62 & 0,02 & 0,04 \\
\hline & Depan & 30,00 & 5,29 & 18,00 & 8,26 & 30,00 & 5,86 & 0,01 & 0,02 \\
\hline & Rata-rata & 29,67 & 5,90 & 27,00 & 8,20 & 30,00 & 5,40 & 0,02 & 0,03 \\
\hline \multirow{4}{*}{ Nain } & Belakang & 29,00 & 6,28 & 30,00 & 8,10 & 29,00 & 5,27 & 0,02 & 0,03 \\
\hline & Tengah & 30,00 & 6,39 & 28,00 & 8,14 & 29,00 & 5,36 & 0,03 & 0,03 \\
\hline & Depan & 30,00 & 5,14 & 2,00 & 8,18 & 30,00 & 6,13 & 0,01 & 0,02 \\
\hline & Rata-rata & 29,67 & 5,94 & 26,67 & 8,14 & 29,33 & 5,59 & 0,02 & 0,03 \\
\hline
\end{tabular}

kekeruhan pada setiap pulau melebihi baku mutu akan tetapi tidak melebihi dari 6 NTU, dan hal ini masih bisa ditolerir oleh mangrove dan biota yang berasosiasi didalamnya. Nilai kekeruhan pada ekosistem mangrove sangat berfluktuasi mengikuti musim, pasang surut, dan curah hujan.

\section{Total Suspended Solid}

Kisaran nilai rata-rata TSS pada keempat pulau ini 26,67mg/l (P.Nain) - 37,92mg/l (P.Mantehage), nilai ini dibawah baku mutu yang ditetapkan yaitu $80 \mathrm{mg} / \mathrm{l}$ (Tabel 1). Sama halnya dengan suhu dan kekeruhan, bagian belakang dari ekosistem mangrove memiliki nilai TSS rata-rata yang tinggi, masukkan dari daratan memberikan kontribusi yang besar akan nilai ini. Pulau Manado Tua dan Nain memiliki nilai yang rendah untuk TSS, hal ini dipengaruhi oleh jumlah penduduk yang ada di pulau ini cenderung lebih sedikit dibandingkan pulau lainnya. Kondisi TSS ini masih dibawah baku mutu air laut untuk biota, akan tetapi sudah melebihi baku mutu air laut untuk kegiatan pariwisata. Nilai TSS ini lebih besar dibandingkan TSS yang ada pada Desa Basaan I sebesar 44 mg/l (Wantasen, 2013). Kisaran TSS yang ada pada perairan mangrove Tanjung Api-api Sumatera Selatan berkisar 27,67 mg/l - 259,33 mg/l, tingginya TSS dan TOM karena pada daerah mulut muara sungai sering terjadi akumulasi sedimen dan bahan organik baik dari daratan maupun dari lautan, kondisi ini dapat mengganggu proses bioekologis ekosistem ini (Ulqodry et al, 2010).

\section{pH}

Kondisi $\mathrm{pH}$ pada perairan ekosistem mangrove pada lokasi penelitian berkisar anatara $8,07-8,20$, kondisi ini masih dalam kisarann baku mutu air laut untuk biota dan kegiatan pariwisata. Nilai $\mathrm{pH}$ berbanding terbalik dengan parameter lainnya, bagian depan lebih tinggi dibandingkan bagian belakang, hal ini diakibatkan pengenceran pada bagian depan lebih tinggi dibandingkan bagian tengah dan belakang (Tabel 1). Nilai $\mathrm{pH}$ rata-rata tertinggi pada Pulau Manado Tua $(8,20)$ dan terendah pada Pulau Bunaken $(8,07)$. Nilai ini tidak jauh berbeda dengan kisaran $\mathrm{pH}$ pada Distrik Liquisa Timor Leste dari 8-8,5 (Jesus, 2012). Kisaran nilai $\mathrm{pH}$ pada ekosistem mangrove di Kabupaten Barru antara 7,3-7,5 (Malik, 2013), Desa Basaan I kisaran pH 7 -7,3 (Wantasen, 2013) dan nilai rata-rata $\mathrm{pH}$ pada ekosistem mangrove di Tuban Denpasar sebesar 7,56. Kajian Ulqodry et al, (2010) pada ekosistem mangrove Tanjung Api-api Sumsel pH air disana berkisar 6,60 8,22, sedangkan Kajian Arizona dan Sunarto, (2009), pada ekosistem mangrove di Jayapura kisaran nilai $\mathrm{pH}$ 
dari 7,00 - 7,67. Perbedaan nilai $\mathrm{pH}$ pada masng-masing daerah perairan sangat dipengaruhi oleh karakteristik oseanografi dan geomorfologi daerah tersebut. Perairan terbuka cenderung memiliki nilai $\mathrm{pH}$ yang lebih tinggi dibandingkan dengan perairan tertutup, pulau kecil memiliki nilai $\mathrm{pH}$ yang cenderung basa dan pulau besar dengan banyak aliran sungai cenderung menurunkan nilai $\mathrm{pH}$ menjadi asam. Mangrove akan tumbuh dan berkembang dengan baik pada kisaran $\mathrm{spH} 6,2-8$ (Arksornkoae, 1993).

\section{Salinitas}

Salinitas perairan ekosistem mangrove rata-rata berkisar antara 29,08 PSU - 30,00 PSU, Pulau dengan nilai rata-rata salinitas terendah adalah Pulau Mantehage (29,08PSU) dan teritnggi adalah Pulau Manado Tua dan Pulau Bunaken (30,00 PSU). Bagian belakang dari ekosistem mangrove yang mendekati daratan memiliki nilai salinitas yang lebih rendah (Tabel 1). Kondisi ini agak berbeda dengan salinitas yang ada pada ekosistem mangrove di Kabupaten Barru yang hanya 26 PSU (Malik, 2013). Salinitas ekosistem mangrove di di sub district Liquisa Timor-Leste berkisar 30-32 PSU (Jesus, 2012), hal ini sama dengan kondisi yang ada pada ekosistem mangrove di Desa Basaan I (Wantasen, 2013), sedangkan salinitas mangrove di Tanjung Apiapi berkisar antara 28-31 PSU (Ulqodry et al, 2010). Kajian Arizona dan Sunarto, (2009), pada ekosistem mangrove di Kampung Tobati dan Nafiri Jayapura mendapatkan hasil pengukuran salinitas yang sangat tinggi, dengan kisaran 33,18 - 45,28 PSU. Salinitas yang tinggi (> $35 \%$ ) dapat berpengaruh buruk bagi vegetasi mangrove, karena dampak dari tekanan osmotik yang negatif (Bengen, 2000). Perubahan salinitas secara spasial tidak berpengaruh langsung terhadap vegetasi tetapi dapat membahayakan biota lain yang berasosiasi dengan vegetasi (Poedjirahajoe, 2007). Peningkatan salinitas dapat menyebabkan kematian bagi biota termasuk fitoplankton sebagai penghasil oksigen, akibatnya kandungan oksigen terlarut di perairan dapat mengalami penurunan. Peningkatan ketebalan lumpur dapat menyebabkan penurunan oksigen terlarut. Hal ini dapat terjadi karena penambahan substrat berasal dari arus pasang yang membawa substrat lumpur sehingga seringkali menyebabkan peningkatan kekeruhan air. Air yang keruh akan menyulitkan penetrasi cahaya masuk ke permukaan air sehingga mengakibatkan fitoplankton tidak dapat berfotosintesis secara optimal, akibatnya jumlah oksigen terlarut yang dihasilkan menjadi lebih rendah (Poedjirahajoe, 2017).

\section{Oksigen terlarut}

Sumber oksigen terlarut dalam air berasal dari difusi oksigen dari udara, arus atau aliran air melalui air hujan serta aktivitas fotosintesis oleh tumbuhan air dan fitoplankton (Novonty \& Olem,
1994). Oksigen diperlukan oleh semua makhluk yang hidup di air seperti ikan, udang, kerang dan hewan lainnya termasuk mikroorganisme seperti bakteri. Oksigen terlarut sebagai pengatur metabolisme tubuh organisme untuk tumbuh dan berkembang biak. Kisaran nilai rata-rata DO pada ekosistem mangrove lokasi penelitian dari 4,73-5,70 mg/l (Tabel 1). Sama halnya dengan salinitas, nilai DO rendah terdapat pada bagian belakang mangrove, dan tinggi pada bagian depan, hal ini dipengaruhi oleh pencampuran massa air yang lebih baik pada bagian depan, dan masukkan dari daratan yang dapat menurunkan nilai DO. Nilai DO perairan ekosistem ini cukup baik karena masih dalam kisaran baku mutu. Berbeda dengan kondisi DO pada perairan ekosistem mangrove di Kabupaten Barru yang mencapai 7,0 - 8,0 mg/l (Malik, 2013), di Desa Basaan I nilai DO berkisar 8,95 - 10,10 mg/l (Wantasen, 2013), sedangkan pada perairan mangrove Tanjung Api-api kisaran DO dari 4,89 - 5,35 mg/l. Kadar oksigen terlarut berfluktuasi secara harian dan musiman tergantung pada pencampuran (mixing) dan pergerakan (turbulence) massa air, aktivitas fotosintesis, respirasi, dan limbah yang masuk ke badan air (Effendi 2003).

\section{Nitrat}

Kandungan nitrat rata-rata dalam perairan ekosistem mangrove keempat pulau ini berkisar antara 0,02 - 0,05 mg/l (Tabel 1), bagian yang berdekatan dengan daratan memiliki nilai yang lebih tinggi dibandingkan yang didepan, hal ini masuk dalam kategori baik karena masih sesuai dengan baku mutu lingkungan. Nilai nitrat ini sangat berbeda dengan kondisi nitrat pada ekosistem mangrove yang ada di Tanjung Api-a pi Sumatera Selatan yang mencapai $1,00 \mathrm{mg} / \mathrm{l}$ (Ulqodry et al, 2010). Di Sungai Buaya Pulau Bunyu Kalimantan Utara nilai nitrat (NO3-N) 0,005 - 0,861 mg/l saat pasang dan 0,004-0,564 mg/l saat surut (Kurniadi et al, 2015), sedangkan kondisi nitrat pada ekosistem mangrove di Tuban Denpasar sebesar 13,5ppm (Suriani, 2006). Kandungan nitrat pada sub district Liquisa Timor-Leste berkisar antara 0,08-0,21 mg/l (Jesus, 2012), dan kandungan nitrat di Kabupaten Barru berkisar 0,005-0,025 mg/l (Malik, 2013). Tinggi rendahnya kandungan nitrat suatu perairan ekosistem mangrove dipengaruhi oleh karakteristik lingkungan tersebut. Nitrat (NO3) adalah bentuk utama nitrogen di perairan alami dan merupakan unsur hara utama bagi pertumbuhan tanaman dan alga. Nitrat nitrogen sangat mudah terlarut dalam air dan bersifat stabil. Senyawa ini dihasilkan dari proses oksidasi sempurna senyawa nitrogen di perairan. Nitrifikasi yang merupakan proses oksidasi amonia menjadi nitrit dan nitrat dengan bantuan mikro-organisme adalah proses yang penting dalam siklus nitrogen (Effendi, 2003). Nitrat (NO3) di perairan laut adalah senyawa mikronutrien pengontrol produktivitas primer di lapisan permukaan 
daerah eufotik. Kadar nitrat di daerah eufotik sangat dipengaruhi oleh transportasi nitrat, oksidasi amoniak oleh mikroorganisme dan pengambilan nitrat untuk proses produktivitas primer. Nitrat adalah bentuk utama nitrogen di perairan alami dan merupakan nutrien utama bagi pertumbuhan tanaman dan alga. Nitrat nitrogen sangat mudah larut dalam air dan bersifat stabil. Senyawa ini dihasilkan dari proses oksidasi sempurna senyawa nitrogen di perairan. Nitrifikasi yang merupakan proses oksidasi amonia menjadi nitrit dan nitrat adalah proses yang penting dalam siklus nitrogen dan berlangsung pada kondisi aerob. Oksidasi amonia menjadi nitrit dilakukan oleh bakteri Nitrosomonas, sedangkan oksidasi nitrit menjadi nitrat dilakukan oleh bakteri Nitrobacter (Schaduw et al, 2013).

\section{Fosfor}

Kandungan fosfor pada perairan keempat pulau memiliki nilai rata-rata dengan kisaran 0,05-0,24 $\mathrm{mg} / \mathrm{l}$, hal ini tergolong baik karena sesuai dengan daya dukung lingkungan perairan untuk kelangsungan hidup biota akuatik dan sesuai dengan baku mutu yang ada (Tabel 1). Pulau Mantehage memiliki nilai yang tertinggi, sedangkan Pulau Manado Tua dan Pulau Nain dengan nilai yang terendah. Perbedaan nilai ini sangat dipengaruhi oleh kondisi ekologis pulau terutama masukkan dari daratan dan arus. Kondisi PO4-P di perairan ekosistem mangrove Kabupaten Barru lebih kecil dibandingkan Pulau Kecil di Bunaken, dengan nilai rata-rata $0,014 \mathrm{mg} / \mathrm{l}$ (Malik, 2013), berbeda halnya dengan kondisi PO4-P yang ada di Desa Basaan I, dimana nilainya berkisar 0,013-0,122 mg/l (Wantasen, 2013), sedangkan nilai PO4-P perairan yang cukup tinggi berada di perairan mangrove Tanjung api-api Sumatera selatan dengan kisaran 0,12 - 0,40 mg/l (Ulqodry et al, 2010). Fosfat merupakan bentuk fosfor yang dapat dimanfaatkan oleh tumbuhan dan merupakan unsur yang esensial bagi tumbuhan tingkat tinggi dan alga, sehingga unsur ini menjadi faktor pembatas bagi tumbuhan dan alga akuatik serta sangat mempengaruhi produktifitas perairan. Berdasarkan kadar fosfor total, perairan diklasifikasikan menjadi tiga, yaitu: perairan dengan tingkat kesuburan rendah, yang memiliki kadar fosfat total berkisar antara $0-0,02 \mathrm{mg} / \mathrm{liter}$; perairan dengan tingkat kesuburan sedang memiliki kadar fosfat total 0,021 - 0,05 mg/liter; dan perairan dengan tingkat kesuburan tinggi, yang memiliki kadar fosfat total 0,051 - 0,1 mg/liter (Effendi, 2003).

\section{Distribusi karakteristik kualitas air ekosistem mangrove}

Hasil analisis PCA yang ada pada Tabel 2 mengindikasikan pengelompokkan delapan karakteristik kualitas air cukup dilakukan dengan menggunkan faktor 1 dan 2 . Kedua faktor ini sudah dapat mejelaskan 94\% (F1=79,33\% ; F2=14,22\%) dari total karakteristik yang ada (Tabel 2 dan Gambar 2). Faktor lainnya tidak lagi digunakan karena tidak memiliki kemampuan yang tinggi dalam menerangkan variasi total atau yang kebih rendah dari kontribusi rata-rata setiap karakter. Delapan karakteristik yang ada memiliki variabel yang berpengaruh nyata terhadap variabel baru. Pada tabel eigenvalues dan tabel factor loadings menunjukkan bahwa faktor utama 1 (F1) merepresentasikan sekitar 79,33\% dari keragaman data dengan variabel penciri utamanya yaitu suhu (nilai factor loadings sebesar 0,3912) dan TSS (nilai factor loadings sebesar -0,3878). Namun variabel TSS berkorelasi negatif, dimana dengan meningkatnya TSS di sisi lain justru dapat menurunkan suhu perairan. Faktor utama 2 (F2) merepresentasikan 14,22\% dari keragaman data, dengan variabel pencirinya PO4-P dengan nilai factor loadings 70,16\%, sedangkan faktor utama 3 (F3) merepresentasikan $6 \%$ dari keragaman data, dengan variabel pencirinya salinitas dengan factor loading $71 \%$, karena direpresentasikan dengan karakteristik faktor loadings yang berbeda, maka tidak terdapat kaitan satu sama lain, hal ini artinya karakteristik bersifat independen. Berbeda halnya dengan kajian Ulqodry et al. (2010) terhadap karakteristik perairan mangrove Tanjung Api-api, untuk Stasiun I (daerah laut) dicirikan oleh suhu, salinitas, DO dan $\mathrm{pH}$ yang tinggi, Stasiun II (daerah muara) lebih dicirikan oleh nilai TOM dan TSS yang tinggi sedangkan Stasiun III (daerah belakang muara/sungai) sedikit dicirikan oleh parameter fisika-kimia air dibandingkan dengan stasiunstasiun yang berada di daerah laut dan muara. Kajian Poedjirahajoe (2017) yang menggunakan PCA dalam menganalisa distribusi spasial vegetasi di Pemalang menggunakan variebel jenis mangrove dan kualitas air sebagai parameter penelitian, hasilnya adalah sebaran spasial karakteristik faktor habitat mangrove pada setiap stasiun pengamatan di Pantai Utara Pemalang membentuk tiga cluster dengan karakteristik habitat yang berbeda. Cluster 1 terdiri dari R. mucronata dan $S$. alba dengan karakteristik habitat berupa $\mathrm{pH}$, salinitas, dan tebal lumpur yang rendah, suhu yang sedang, dan oksigen terlarut yang tinggi. Cluster 2 tersusun oleh Acanthus ilicifolius, Avicennia alba, dan R. apiculata dengan karakteristik habitat berupa suhu yang rendah serta tebal lumpur, $\mathrm{pH}$, oksigen terlarut, dan salinitas yang sedang. Cluster 3 berupa Avicennia marina dengan karakteristik habitat berupa $\mathrm{pH}$, salinitas, suhu, dan tebal lumpur yang tinggi serta oksigen terlarut yang rendah. 
Joshian Nicolas William Schaduw/Majalah Geografi Indonesia, Vol. 32, No. 1, Maret 2018 : 40 - 49

Tabel 2. Eigenvalue dan Eigenvectors faktor hasil PCA terhadap variabel karakteristik

\begin{tabular}{llccccccc}
\hline Eigenvalues & $\mathbf{1}$ & $\mathbf{2}$ & $\mathbf{3}$ & $\mathbf{4}$ & $\mathbf{5}$ & $\mathbf{6}$ & $\mathbf{7}$ & $\mathbf{8}$ \\
\hline Value & 6,3464 & 1,1378 & 0,5158 & 0,0000 & 0,0000 & 0,0000 & 0,0000 & 0,0000 \\
\% of variability & 0,7933 & 0,1422 & 0,0645 & 0,0000 & 0,0000 & 0,0000 & 0,0000 & 0,0000 \\
Cumulative \% & 0,7933 & 0,9355 & 1,0000 & 1,0000 & 1,0000 & 1,0000 & 1,0000 & 1,0000 \\
\hline Vectors : & $\mathbf{1}$ & $\mathbf{2}$ & $\mathbf{3}$ & $\mathbf{4}$ & $\mathbf{5}$ & $\mathbf{6}$ & $\mathbf{7}$ & $\mathbf{8}$ \\
\hline Suhu & 0,3912 & $-0,0538$ & $-0,2212$ & $-0,2453$ & $-0,3482$ & 0,7682 & 0,0673 & $-0,1376$ \\
Kekeruhan & 0,3817 & 0,0268 & $-0,3797$ & 0,1400 & 0,5739 & 0,0985 & $-0,5230$ & 0,2777 \\
TSS & $-0,3878$ & 0,1580 & 0,1819 & 0,3072 & $-0,2923$ & 0,3636 & $-0,2303$ & 0,6530 \\
pH & 0,3045 & 0,5982 & $-0,0906$ & 0,6170 & $-0,0381$ & $-0,0118$ & 0,3848 & $-0,1037$ \\
Salinitas & 0,3370 & 0,1188 & 0,7146 & $-0,2591$ & 0,3761 & 0,1557 & 0,2452 & 0,2624 \\
DO & $-0,3692$ & $-0,2663$ & $-0,3236$ & 0,0739 & 0,4542 & 0,2814 & 0,6090 & 0,1619 \\
NO3-P & $-0,3812$ & 0,1904 & 0,2659 & 0,1562 & 0,3317 & 0,4028 & $-0,2991$ & $-0,6013$ \\
PO4-P & $-0,2507$ & 0,7016 & $-0,2821$ & $-0,5900$ & 0,0685 & $-0,0456$ & 0,0197 & 0,1005 \\
\hline
\end{tabular}
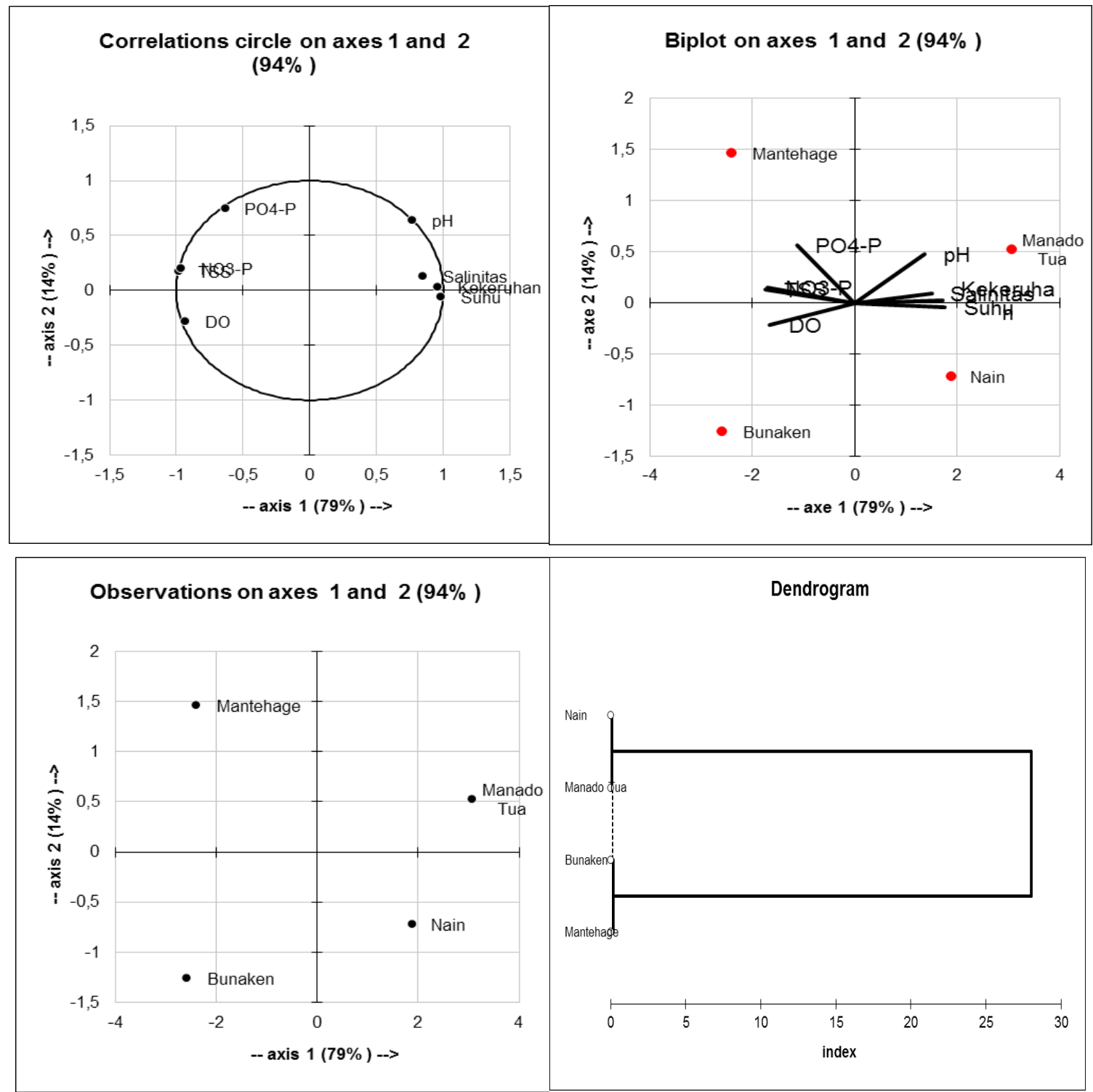

Gambar. Sebaran dan Pengelompokkan Karakteristik Kualitas Air 
Pulau Mantehage dicirikan oleh tingginya nilai TSS, NO3-N dan PO4-P, sedangkan Pulau Bunaken dicirikan oleh DO yang cukup tinggi (Gambar 2), akan tetapi Pulau Mantehage dan Pulau Bunaken kesamaannya dicirikan nilai suhu yang rendah (Cluster 1). Pulau Manado Tua dicirikan dengan tingginya nilai $\mathrm{PH}$, salinitas, dan kekeruhan sedangkan Pulau Nain dicirikan oleh tingginya nilai suhu, kesamaannya Pulau Manado Tua dan Pulau Nain dicirikan dengan nilai kekeruhan yang rendah (Cluster 2). Dendogram memperlihatkan hasil analisis cluster pada dua tingkatan tersebut (Gambar 2)

\section{KESIMPULAN}

Kondisi perairan ekosistem mangrove pada keempat pulau lokasi penelitian dalam kondisi baik dan masih sesuai dengan baku mutu lingkungan yang ada, hal ini mengindikasikan bahwa proses bioekologis pada daerah ini dapat berjalan dengan baik, dan belum mengalami perubahan yang signifikan. Hasil PCA menggambarkan korelasi karakteristik kualitas air sebesar $94 \%$ yang terdiri dari faktor utama 1 (F1) 79,33\% dan faktor utama 2 (F2) 14,22\% dengan penciri utama suhu, PO4-P, dan salinitas, sedangkan hasil Cluster analisis mengelompokkan empat pulau kecil ini dalam 2 cluster, Culster 1 Pulau Mantehage dan Pulau Bunaken yang dicirikan oleh suhu, DO, TSS, NO3-N dan PO4-P, sedangkan Cluster 2 Pulau Manado Tua dan Pulau Nain dicirikan oleh nilai PH, salinitas, dan kekeruhan. Kondisi kualitas air ini harus terus dipertahanankan dan dimonitoring untuk memastikan tidak adanya perubahan yang dapat mengganggu ekosistem mangrove pulau kecil yang ada di Taman Nasional Bunaken.

\section{UCAPAN TERIMA KASIH}

Penulis mengucapkan terima kasih kepada Balai Taman Nasional Bunaken (BTNB); Dewan Pengelolaa Taman Nasional Bunaken (DPTNB); Pemerintah Kota Manado; Dinas Kelautan dan Perikanan Provinsi Sulut; dan Laboratorium Teknologi Akuakultur FPIK UNSRAT, atas semua bantuan material dan imaterial serta kerjasamanya selama kajian ini dilaksanakan.

\section{DAFTAR PUSTAKA}

Aksornkoae S. (1993). Ecology and Management of Mangrove. IUCN. Bangkok. Thailand.

Alimuna W, Sunarto, Sigit H. (2009). Pengaruh Aktivitas Masyarakat Terhadap Kerusakan Hutan Mangrove Di Rarowatu Utara, Bombana Sulawesi Tenggara. Majalah Geografi Indonesia. 23 (2)

Arizona M dan Sunarto. (2009). Kerusakan Ekosistem Mangrove Akibat Konversi Lahan Di Kampung Tobati Dan Kampung Nafri, Jayapura. Majalah Geografi Indonesia. 23 (3) : 18 - 39
Bakus GJ. (2007). Quantitatif Analysis of Marine Biological Communities Field Biology and Environmental. New Jersey: John Wiley \& Sons Inc.

Bengen DG. (2002). Pedoman Teknis Pengenalan dan Pengelolaan Ekosistem Mangrove. Pusat Kajian Sumberdaya Pesisir dan Lautan.IPB. Bogor.

Bengen DG. (2000). Pengenalan dan Pengelolaan Ekosistem Mangrove. Pusat Kajian Sumberdaya Pesisir dan Lautan.IPB. Bogor.

Effendi H. (2003). Telaah Kualitas Air Bagi Pengelolaan Sumber Daya dan Lingkungan Perairan. Kanisius, Yogyakarta.

Hilmi E, AA Siregar, L Febryanni, R Novaliani, S Amir dan AD Syakti. (2015). Struktur Komunitas, Zonasi Dan Keanekaragaman Hayati Vegetasi Mangrove Di Segara Anakan Cilacap. Omniakuatika, 11 (2): 20-32

Jesus A. (2012). Kondisi Ekosistim Mangrove Di Sub District Liquisa Timor-Leste. Depik 1(3): 136143

Kurniadi B, Sigid H, Enan M, Adiwilaga. (2015). Kualitas Perairan Sungai Buaya di Pulau Bunyu Kalimantan Utara pada Kondisi Pasang Surut. Jurnal Ilmu Pertanian Indonesia (JIPI) 20 (1): 5358

Kolehmainen S, T Morgan and R Castro. (1974). Mangrove Root Communities in A Thermally altered area in Guayanilla Bay. In Gibbons, J.W., and R.R. Sharitz (Eds) Thermal Ecology. U.S. atomic energy Commission.

Legendre P and L Legendre. (2014). Numerical Ecology, Developments In Enviromental Modelling. Elsevier.

Ludwig JA and JF Reynolds. (1988). Statistical Ecology: A Primer on Methods and Computing. John Willey \& Sons. Singapore.

Malik A. (2013). Analisis Kualitas Air Pada Kerapatan Mangrove Yang Berbeda Di Kabupaten Barru. Octopus. 2 (2) : 159-193

Matan Opm, Djoko M, Ritohardoyo (2010). Keanekaragaman Dan Pola Komunitas Hutan Mangrove di Andai Kabupaten Manokwari. Majalah Geografi Indonesia. 24 (1) 36-53Nonji A. (2005). Laut Nusantara. Penerbit Djambatan. Jakarta.

Novonty V and Olem H. (1994) Water Quality, Prevention, Identification And Management Of Diffuse Pollution. Van Nostrans Reinhold. New York

Poedjirahajoe E. (2007). Dendogram Zonasi Pertumbuhan Mangrove Berdasarkan Habitatnya di kawasan rehabilitasi pantai utara jawa tengah bagian barat. Jurnal Ilmu Kehutanan. 1 (2) : 10-21 
Poedjirahajoe E, Ragil W, Ni Putu Diana M. (2011). Kajian Ekosistem Mangrove Hasil Rehabilitasi Pada Berbagai Tahun Tanam Untuk Estimasi Kandungan Ekstrak Tanin Di Pantai Utara Jawa Tengah. Jurnal Ilmu Kehutanan. 5 (2) : 99-107

Poedjirahajoe E, Djoko M, F Kusuma (2017). Penggunaan Principal Component Analysis Dalam Distribusi Spasial Vegetasi Mangrove Di Pantai Utara Pemalang. Jurnal Ilmu Kehutanan 11 : 2942

Schaduw JNW.(2012). Pengelolaan Ekosistem Mangrove Pulau Kecil Berbasis Mitigasi (Kasus Pulau Kecil Taman Nasional Bunaken). Disertasi (Tidak dipublikasikan). IPB.

Schaduw JNW, Edwin N, Joppy M. (2013). Land Suitability Of Seaweed Farming In Minahasa Regency, North Sulawesi Province. Aquatic Science \& Management. 1 (1) : 72-81

Schaduw JNW. (2016). Kondisi Ekologi Mangrove Pulau Bunaken Kota Manado Provinsi Sulawesi Utara. Jurnal Sains Lppm Unsrat. 3 (2) : 64-74

Suriani LH. (2006). Kualitas Air Mangrove Ditinjau Dari Sifat Fisik-Kimia Di Hutan Mangrove Patung Ngurah Rai Tuban Denpasar Selatan Bali. Ecotrophic 3 (1) : 7 - 9

Ulqodry TZ, Dietriech GB, Richardus FK. (2010). Karakteristik Perairan Mangrove Tanjung Api-Api Sumatera Selatan Berdasarkan Sebaran Parameter Lingkungan Perairan Dengan Menggunakan Analisis Komponen Utama (PCA). Maspari Journal $1: 1$ 6- 21

Wantasen AS. (2013). Kondisi Kualitas Perairan Dan Substrat Dasar Sebagai Faktor Pendukung Aktivitas Pertumbuhan Mangrove Di Pantai Pesisir Desa Basaan I, Kabupaten Minahasa Tenggara. Jurnal Ilmiah Platax. 1 (4): 204-209 